\title{
PEAT-FORMING ENVIRONMENT OF COAL-BEARING PERMIAN SEDIMENTS IN KACHINAPALLI AREA OF GODAVARI GRABEN, INDIA
}

\author{
NEERJA JHA \& NEHA AGGARWAL \\ Birbal Sahni Institute of Palaeobotany, 53 University road, Lucknow 226 007, India. \\ neha_264840@yahoo.co.in
}

\begin{abstract}
This article integrates palaeobotanical and palynological analysis to establish palynostratigraphic succession and depositional environment for the borecore MGK-6 from Kachinapalli area of Lingala-Koyagudem coal belt of Godavari Graben, South India. Palynological analysis in sub-surface sediments of $490.10 \mathrm{~m}$ deep borecore have divulged occurrence of three palynoassemblages. Palynoassemblage I at $314.25-346.65 \mathrm{~m}$ is marked by dominance of nonstriate disaccates Scheuringipollenites maximus, S. tentulus along with subdominance of few striate disaccates chiefly Striatopodocarpites decorus, Faunipollenites (=Protohaploxypinus) varius, F. bharadwajii. Palynoassemblage II at 220.70-298 $\mathrm{m}$ is characterized by dominance of striate disaccates viz., Striatopodocarpites tiwarii, Faunipollenites bharadwajii, Striatites varius, Strotersporites indicus, S. communis, Lunatisporites diffuses, L. ovatus with subdominance of nonstriate disaccates Scheuringipollenites maximus, S. tentulus and Ibisporites jhingurdahiensis. Palynoassemblage III identified at 46.75-206.70 m shows dominance of striate disaccates viz., Striasulcites ovatus, Striatopodocarpites diffuses, S. tiwarii, Faunipollenites bharadwajii, F. varius, F. parvus, F. goraensis and Crescentipollenites globosus, C. brevis along with a number of stratigraphically significant taxa viz., Strotersporites indicus, Lunatisporites diffusus, Corisaccites alutas, Guttulapollenites hannonicus, Klausipollenites sp., Falcisporites zapfei, F. nuthallensis, Weylandites circularis, Striomonosaccites circularis and Chordasporites sp. Palynoassemblage I (Barakar palynoflora) belongs to Artinskian age while, Palynoassemblages II and III (Raniganj palynoflora) belongs to Guadalupian age. The dominance of arborescent vegetation (glossopterids and conifers), low proportion of spores (lycopsids, sphenopsids and filiciopsids) and scare presence of algal elements suggests that Kachinapalli palaeomire landscape was located in more inland area and the coal was formed in peat swamp forest environment situated in fresh water settings.
\end{abstract}

Key words: Permian, Artinskian, Guadalupian, Gondwana, Godavari Graben, India.

RESUMO - Este artigo integra análises paleobotânicas e palinológicas para estabelecer sucessão palinostratigráfica e ambiente de sedimentação com base no testemunho de sondagem MGK-6, da área de Kachinapalli, cinturão de carvão de Lingala-Koyagudem, Godavari Graben, sul da Índia. Análise palinológica em sedimentos de poços de sondagem que atingiram até $490,10 \mathrm{~m}$ de profundidade, mostraram ocorrências de três palinoassembleias. A Palinoassembleia I entre 314,25-346,65 m, é marcada pelo domínio de dissacados não estriados Scheuringipollenites maximus, S. tentulus associados ao sub-domínio de alguns dissacados estriados principalmente Striatopodocarpites decorus, Faunipollenites (= Protohaploxypinus) varius, F. bharadwajii. Palinoassembleia II, entre 220,70-298 m, se caracteriza pelo domínio de dissacados estriados viz., Striatopodocarpites tiwarii, Faunipollenites bharadwajii, Striatites varius, Strotersporites indicus, S. communis, Lunatisporites difundes, L. ovatus com subdomínio de dissacados não estriados Scheuringipollenites maximus, S. tentulus e Ibisporites jhingurdahiensis. A Palinoassembleia III, identificada entre 46,75-206,70 m mostra predomínio de dissacados estriados viz., Striasulcites ovatus, Striatopodocarpites diffuses, S. tiwarii, Faunipollenites bharadwajii, F. varius, F. parvus, F.goraensis e Crescentipollenites globosus, C. brevis, junto a vários táxons estratigraficamente significativos viz., Strotersporites indicus, Lunatisporites diffusus, Corisaccites alutas, Guttulapollenites hannonicus, Klausipollenites sp., Falcisporites zapfei, F. nuthallensis, Weylandites circularis, Striomonosaccites circularis e Chordasporites sp. A Palinoassembleia I (palinoflora Barakar) é de idade artinskiana enquanto as Palinoassembleias II e III (palinoflora Raniganj) pertencem à idade guadalupiana. O predomínio de vegetação arborescente (glossopterídeas e coníferas), baixa proporção de esporos (licófitas, esfenófitas e filicófitas) e presença esparsa de elementos de algálicos sugerem que a paisagem turfosa de Kachinapalli estava localizada na área intercontinental e o carvão foi formado em pântanos turfosos com florestas, situados em ambientes de água doce.

Palavras-chave: Permiano, Artinskiano, Guadalupiano, Gondwana, Graben Godavari, Índia. 


\section{INTRODUCTION}

As the Godavari Graben is affected by many small faults and the effect of faults are varying within the sub-basins, the coal seams cannot be fitted into universal pattern of basin evolution, and hence the dating and correlation of coal seams is the basic requirement in this area. Well identified palynomorphs assemblages are efficiently helpful in the palynostratigraphic correlation of coal seams because of their restricted distribution in time and space. Pollen and spores present in various coal bearing horizons are quite different in their morphological as well as their numerical characters, because of that a specific group of spore and pollen (palynoassemblage) acquaint within the particular horizon. By the quantitative and qualitative study of these spores and pollen, coal seams and their associated sediments are recognized which become helpful in dating and correlation. Present communication is based on the quantitative and qualitative palynofloral composition and botanical affinities of palynoflora among distinct palynoassemblages.

\section{GEOLOGY AND LOCATION}

The Godavari Graben is a linear NNW-SSE trending coal belt on Precambrian/Vindhyan platform, extending from north of Boregaon, Maharashtra in the north to Eluru in the east coast of Andhra Pradesh, India, covering a surface area of $17,000 \mathrm{~km}^{2}$. In this linear belt the Lower Gondwana sediments are exposed along both the eastern and western margins of the basin while the upper Gondwana sediments cover the central/axial portion. Basin comprises four structural sub basins (Godavari, Kothagudem, Chintalapudi and coastal Krishna Godavari) (Raja Rao, 1982). Godavari
Graben holds a unique position not only because it is the only coal producing area in the south India but also because it has more or less a complete succession from Permian to Cretaceous sediments.

Out of 15 identified coal belts in Godavari Graben, LingalaKoyagudem coal belt has been dealt for the present study. A $50 \mathrm{~km}$ long unbroken stretch of Barakar Formation occurring between Lingala in the north west to Koyagudem in the south east on western margin of Godavari Valley coalfield is named as Lingala-Koyagudem coal belt. The coal belt is bounded by North latitude $17^{\circ} 35^{\prime}$ to $18^{\circ} 00^{\prime}$ and East longitude of $80^{\circ} 03^{\prime}$ to $80^{\circ} 30^{\prime}$ in the Survey of India Toposheet Nos. 65 B/8 and 65 $\mathrm{C} / 5, \mathrm{C} / 6$ and $\mathrm{C} / 10$ spread over an area of $192 \mathrm{~km}^{2}$ of Khammam district, South India. This coalbelt is studied between the two active mining centers of Ramagundam in the northwest and Kothagudem in the southwest.

It covers the entire Lower Gondwana succession from Talchir (Asselian) to late Raniganj Formation (Lopingian). These formations are generally trended to NW-SE, with north easterly dips ranging from $10^{\circ}$ to $20^{\circ}$ with the local variations (Figure 1). The generalized stratigraphic succession in Kachinapalli block, as delimited by Mineral Exploration Corporation Limited (MECL) 2002, is given in Table 1.

\section{MATERIAL AND METHODS}

Borecore MGK-6, which provided basic core material ( $490.10 \mathrm{~m}$ deep) for the present study, was drilled by Mineral Exploration Corporation Limited (Figure 1). Total 35 samples of different lithologies viz., clay, carbonaceous shale, coal, grey shale, sandstone etc. has been collected. Extraction of the palynomorphs from the samples was carried out using an established procedure of maceration which includes crushing

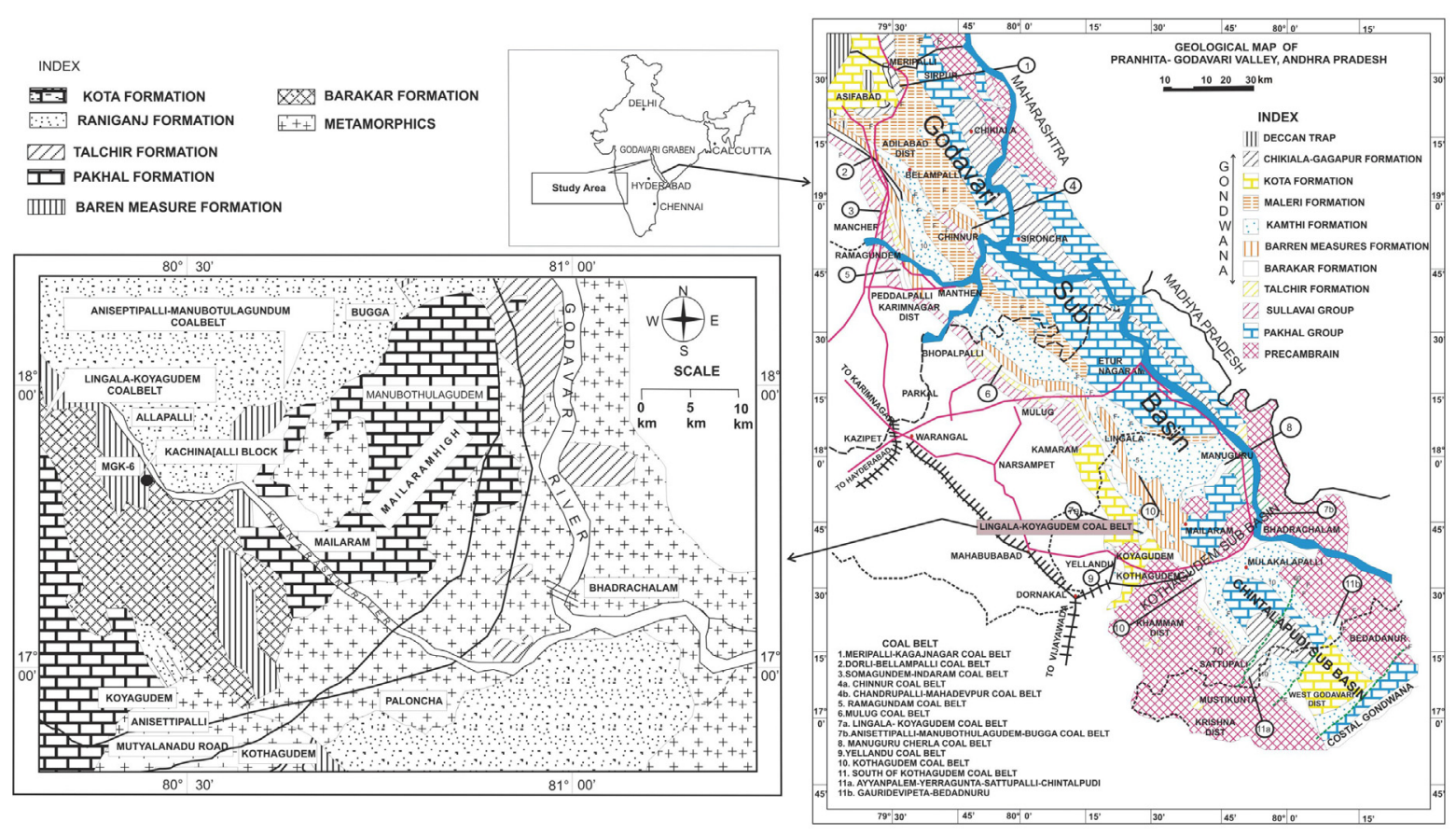

Figure 1. Map showing location of borecore MGK-6 in Lingala-Koyagudem coalbelt. 
Table 1. Showing generalized stratigraphic succession in Kachinapalli block.

\begin{tabular}{lll}
\hline Group & Formation & Lithology \\
\hline----- Soil Cover ----- & Kamthi & Sandstone with subordinate shales and coal seams \\
& Barren Measures & Grey to greenish grey coarse to pebbly feldspathic sandstone with shale bands \\
LOWER & Barakar & $\begin{array}{l}\text { Predominantly medium to coarse grained, grey white sandstone, altered feldspars } \\
\text { with subordinate clays/shales and persistant coal seams }\end{array}$ \\
GONDWANA & Fine to medium grained pale green sandstone with occasional olive green shales \\
& Talchir & Quartzites, phyllites and dolomites \\
\hline
\end{tabular}

(5-10 gm/sample) followed by 2-4 days hydrofluoric acid treatments. After thorough washing of water post hydrofluoric acid organic residues were oxidized with nitric acid for 2-5 days followed by $10 \% \mathrm{KOH}$ treatment. Preparation of the slides was done in Canada balsam with the help of Polyvinyl Chloride (PVC). The scanning of slides and the photography of the palynomorphs were done with DP25 Olympus digital camera mounted on a BX62 microscope. The collected samples and prepared palynological slides are housed at the museum of Birbal Sahni Institute of Palaeobotany, Lucknow, India. Botanical affinity of dispersed spores and pollen such as lycopsids, sphenopsids, filicopsids, glossopterids, cordaites, conifers and others were based on anthology of Balme (1995).

\section{RESULTS}

\section{Lithological attributes}

Lithologically, strata from 6-306.20 m in borecore MGK-6 have been designated as Kamthi Formation; while sediments from 306.50-475.30 m have been identified as Barren Measures and the succession from 475.41-490.10 $\mathrm{m}$ have been demarcated as Barakar (Figure 2). The borecore was closed at $490.10 \mathrm{~m}$ depth. During Permian, cyclic deposition of sandstone, shale and coal seams has been frequently observed. Similar type of the cyclic sedimentation has been examined in the present succession. In the whole succession four complete cycles has been observed. This cyclic sedimentation of the succession shows a clear picture of the fluvial river channel deposit along with some sub-environments like flood plain, lake, lagoon, swamp and wetlands. Sandstone/siltstone symbolize the river channel deposits, the clay mudstone deposited in very low energy environment (flood plain/deep Lake), carbonaceous shale would be represented by low energy regime (swamp/lake/flood plain/leeves) (Gore, 2010). So, lithological characteristics depict the fluvial settings for the borecore MGK-6.

\section{Palynological attributes}

Palynology and the palaeobotany of the depositional palynomorphs along with lithology are usually the main tools to be used to define the features of depositional environments. The palynological composition of the succession has been extensively used to distinguish the palaeoenvironment, considering that flora is very susceptible to minor ecological changes, reflected in palaeoflora (Smith, 1962).

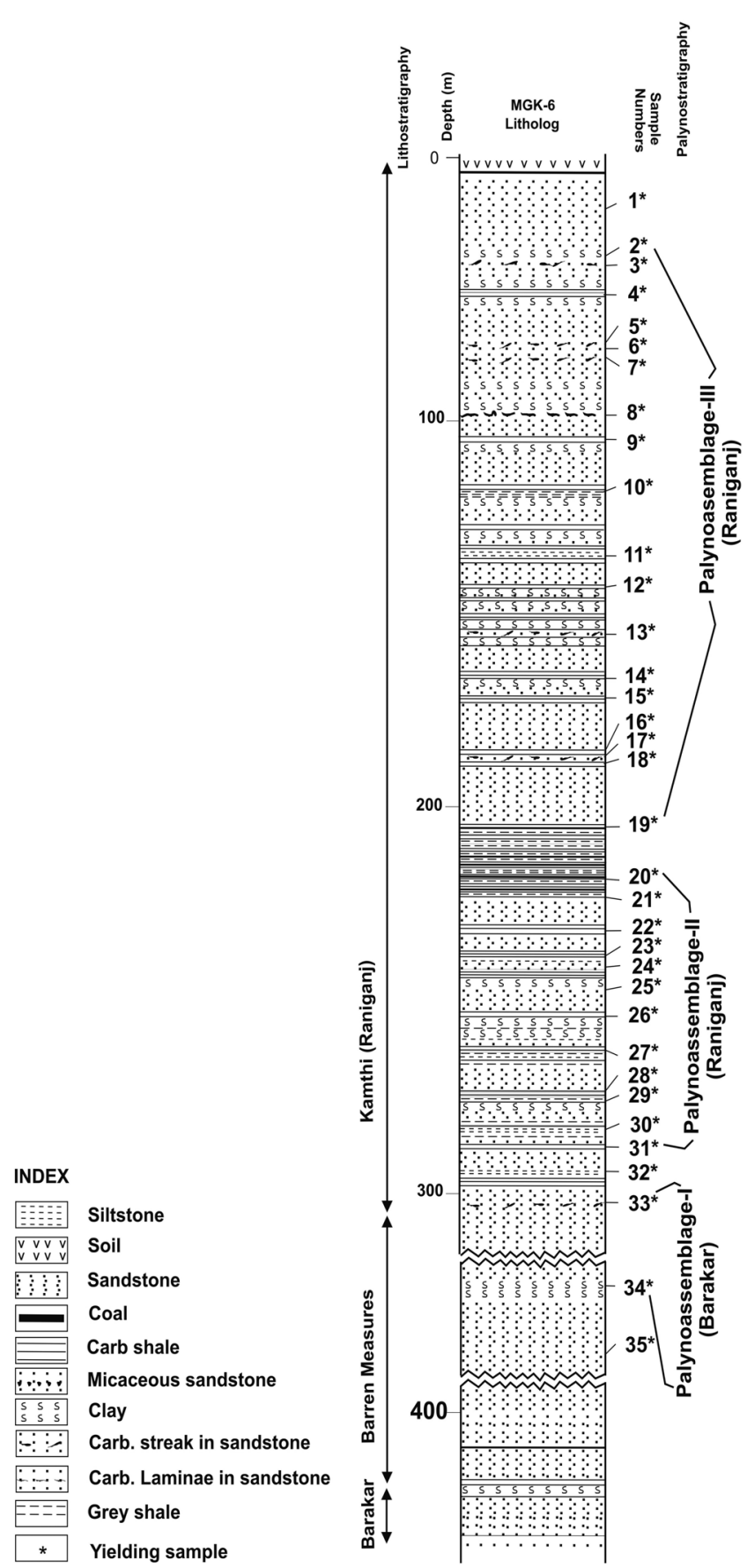

Figure 2. Litholog of borecore MGK-6 showing positions of samples and palynoassemblages in different formations. 
During palynological studies of the studied borecore, forty three genera and fifty six species were indentified from thirty five samples including stratigraphically significant taxa. A list of all palynomorphs species is given in Table 2 and stratigraphically significant taxa are displayed in plate (Figure 3 ). The quantitative character of different identified palynoassemblages is shown in histogram (Figures 4, 5). Yielding of the samples was good; in most of the cases at least 200 palynomorphs per sample were counted. After the palynological examination of these 35 samples, on the basis of the distribution pattern and composition of palynoflora, the details of three distinct palynoassemblages are discussed.

\section{Palynoassemblage I}

Recorded palynoflora. Palynoassemblage-I has been documented between 314.25-346.65 m (samples 33-34, Figures $2,7)$ in having the dominance of Scheuringipollenites $(49 \%)$ and the sub dominance of striate disaccates viz., Striatopodocarpites (15-17.5\%) and Faunipollenites (4-12.5\%). Other associated genera in this palynoassemblage are Brevitriletes $(0.5 \%)$, Lophotriletes $(0.5 \%)$, Microbaculispora $(0.5 \%)$, Caheniasaccites (0.5\%), Parasaccites (2.5\%), Densipollenites (0.5-2.5\%), Plicatipollenites (2.5-3\%), Ibisporites (77.5\%), Platysaccus (1.5-2.5\%), Crescentipollenites (1\%), Strotersporites $(0.5 \%)$, Weylandites $(0.5 \%)$, Hamiapollenites (2.5-3\%) and Inaperturopollenites (1-11\%).

Botanical affinity. The palynological content of Palynoassembalge-I from borecore MGK-6 analysed, with a dominance of non-striate disaccate pollen gains $(>50 \%)$ produced by arborescent vegetation with the following species Scheuringipollenites maximus, S. tentulus, Ibisporites jhingurdahiensis, reflectes the remarkable presence of glossopterids (Figure 6) in the palaeovegetaion (Gould \& Delevoryas, 1977). Striate disaccates pollen grains, reflecting the presence of conifers $(30 \%)$ are represented by mainly Striatopodocarpites decorus, Faunipollenites (= Protohaploxypinus) varius and F. bharadwajii. Cordaites (Monosaccates grains: 9\%) show low species diversity represented by Caheniasaccites distinctus, C. ovatus, C. ellipticus, Plicatipollenites indicus, Densipollenites invisus and Parasaccites distinctus, P. korbaensis, P. obscurus. So, in the palaeoplant communities' cordaites also represent their significant presence. Rare presences of filicopsids are represented by Lophotriletes rectus, Microbaculispora sp., Brevitriletes communis and Brevitriletes unicus. Inaperturopollenites (conifer swamp tree: Balme, 1995) nearly $11 \%$ also shows the significant presence in this palaeoevegetation.

Age. Artinskian age (Aggarwal \& Jha, 2013).

Comparison. Palynoassemblage I shows its close resemblance with Palynozone-4 of Ramakrishnapuram (Srivastava \& Jha, 1992a), Manuguru area (Srivastava \& Jha, 1992b), Scheuringipollenites barakarensis (Zone III A) Assemblage Zone (Tiwari \& Tripathi, 1992; Damodar Basin), Assemblage-B of Wardha Coalfield (Bhattacharrya, 1997), Assemblage-II of Talcher Coalfield (Tripathi,
1997); Sohagpur Coalfield (Ram-Awatar et al., 2003); Palynozone-3 of Mailaram area (Jha \& Aggarwal, 2012). This palynoassemblage is also tentatively akin to Vesicaspora zone of Ketewaka Coalfield in Tanzania (Manum \& Tien, 1973); Scheuringipollenites-dominant palynoassemblage of Namwele-Mkomolo and Moze coalfields in Tanzania (Semkiwa et al., 1998).

\section{Palynoassemblage II}

Recorded palynoflora. At the depth of 220.70-298 m (samples 20-31, Figures 2, 7) Palynoassemblage II has been identified by the dominance of striate disaccates viz., Faunipollenites (11.5-53\%), Striatopodocarpites (20.5-47.5\%) and subdominance of Scheuringipollenites (8.5-41.5\%). Other identified genera in Palynoassemblage II are Lacinitriletes $(0.5 \%)$, Callumispora (0.5\%), Leiotriletes $(0.5 \%)$, Verrucosisporites $(0.5 \%)$, Horriditriletes $(0.5 \%)$, Brevitriletes (0.5-1\%), Plicatipollenites (0.5-1\%), Densipollenites (1.5\%), Caheniasaccites (1-2\%), Parasaccites (0.5-2\%), Platysaccus (0.5-1.5), Ibisporites (1-10.5\%), Crescentipollenites (1-2\%), Striasulcites (2\%), Striatites (1-12\%), Latosporites (0.5-8.5\%), Vestigisporites $(0.5 \%)$ and Inaperturopollenites $(0.5 \%)$. Beside these some stratigraphically significant taxa viz., Chordasporites (0.5-3\%), Falcisporites (0.5$1 \%)$, Strotersporites (0.5-2.5\%), Hamiapollenites (1-3\%), Weylandites (1.5\%) and Lunatisporites (0.5-9\%) have also been marked in the palynoassemblage.

Botanical affinity. The palynofloral content of Palynoassembalge II is represented by the dominance of conifers ( $>50 \%$ ) mainly represented by Faunipollenites bharadwajii, F. (=Protohaploxypinus) varius, Striatopodocarpites tiwarii, Lunatisporites diffusus, L. ovatus, L. pellucidus. Glossopterids are subdominant mainly represented by Scheuringipollenites maximus, S. tentulus, Ibisporites jhingurdahiensis. Cordaites are very less (Figure 6) which are represented by Parasaccites distinctus, P. korbaensis, P. obscures, Densipollenites indicus, D. magnicorpus, Plicatipollenites ganjraensis, Caheniasaccites sp. Spores (11.5\%) are represented by Filicopsids (Horriditriletes rampurensis, Brevitriletes communis, B. unicus, Verrucosisporites gondwanensis), lycopsids (Callumispora sp.) and sphenopsids (Latosporites colliensis).

Age. Guadalupian age (Aggarwal \& Jha, 2013).

Comparison. Palynoassemblage II compares well with Striatopodocarpites + Faunipollenites Assemblage zone (zone V-A; lies under Gondisporites raniganjensis) of Tiwari \& Tripathi (1992). It also compares well with Assemblage-I of Chelpur area (Srivastava \& Jha, 1986); Assemblage-I of Mantheni Area (Bharadwaj et al., 1987); Pali Formation of South Rewa Basin (Tiwari \& Ram-Awatar, 1989); Palynozone-5 of Sattupalli area (Srivastava \& Jha, 1994); Kamthi Formation of Kamptee Coalfield (Srivastava \& Bhattacharya, 1996); Assemblage-III of Sohagpur Coalfield (Ram Awatar, 1996); Palynoassemblage I of Bottapagudem area of Chintalapudi sub basin (Jha, 2004); Palynozone-4 of Mailaram area (Jha \& Aggarwal, 2012). 
Table 2. List of taxa recorded in borecore MGK-6, Kachinapalli area, Godavari Graben.

\begin{tabular}{|c|c|c|c|}
\hline Palynotaxa & Early Permian & Late Permian & $\begin{array}{l}\text { Botanical Affinity } \\
\text { (Balme,1995) }\end{array}$ \\
\hline Lophotriletes rectus Bharadwaj \& Salujha, 1964 & + & & \multirow{2}{*}{ Filicopsids } \\
\hline Microbaculispora sp. & + & & \\
\hline Caheniasaccites distinctus Lele \& Makada, 1972 & + & & \multirow{4}{*}{ Cordaites } \\
\hline Caheniasaccites ovatus Bose \& Kar, 1966 & + & & \\
\hline Caheniasaccites ellipticus Bose \& Maheshwari, 1968 & + & & \\
\hline Plicatipollenites indicus Lele, 1964 & + & & \\
\hline Ibisporites diplosaccus Tiwari, 1968 & + & & \multirow[t]{2}{*}{ Glossopterid } \\
\hline Striatopodocarpites decorus Bharadwaj \& Salujha, 1964 & + & & \\
\hline Strotersporites $\mathrm{sp}$. & + & & \multirow[t]{2}{*}{ Conifers } \\
\hline Hamiapollenites sp. & + & & \\
\hline Densipollenites invisus Bharadwaj \& Salujha, 1964 & + & & Cordaites \\
\hline Brevitriletes communis Bharadwaj \& Srivastava emend Tiwari \& Singh, 1981 & + & + & \multirow{2}{*}{ Filicopsids } \\
\hline Brevitriletes unicus (Tiwari) Bharadwaj \& Srivastava emend Tiwari \& Singh, 1981 & + & + & \\
\hline Parasaccites distinctus Tiwari, 1965 & + & + & \multirow{3}{*}{ Cordaites } \\
\hline Parasaccites korbaensis Bharadwaj \& Tiwari, 1964 & + & + & \\
\hline Parasaccites obscurus Tiwari, 1965 & + & + & \\
\hline Scheuringipollenites maximus (Hart) Tiwari, 1973 & + & + & \multirow{4}{*}{ Glossopterids } \\
\hline Scheuringipollenites tentulus (Tiwari) Tiwari, 1973 & + & + & \\
\hline Ibisporites jhingurdahiensis Sinha, 1972 & + & + & \\
\hline Platysaccus plicatus Bharadwaj \& Dwivedi, 1981 & + & + & \\
\hline Striatopodocarpites tiwarii Bharadwaj \& Dwivedi, 1981 & + & + & \multirow{4}{*}{ Conifers } \\
\hline Faunipollenites varius Bharadwaj, 1962 & + & + & \\
\hline Faunipollenites bharadwajii Maheshwari, 1967 & + & + & \\
\hline Crescentipollenites fuscus (Bharadwaj) Bharadwaj, Tiwari \& Kar, 1974 & + & + & \\
\hline Weylandites circularis Bharadwaj \& Srivastava, 1969 & + & + & \multirow{2}{*}{ Others } \\
\hline Inaperturopollenites $\mathrm{sp}$. & + & + & \\
\hline Callumispora sp. & & + & Lycopsid \\
\hline Leiotriletes sp. & & + & \multirow{2}{*}{ Filicopsids } \\
\hline Horriditriletes rampurensis Tiwari, 1968 & & + & \\
\hline Lacinitriletes sp. & & + & Others \\
\hline Indotriradites sp. & & + & Lycopsid \\
\hline Verrucosisporites gondwanensis Srivastava, 1970 & & + & \multirow{2}{*}{ Filicopsids } \\
\hline Microfoveolatispora sp. & & + & \\
\hline Caheniasaccites sp. & & + & \multirow{6}{*}{ Cordaites } \\
\hline Densipollenites indicus Bharadwaj, 1962 & & + & \\
\hline Densipollenites magnicorpus Tiwari \& Rana, 1981 & & + & \\
\hline Divarisaccus sp. & & + & \\
\hline Potonieisporites sp. & & + & \\
\hline Plicatipollenites ganjraensis Saxena, 1971 & & + & \\
\hline Klausipollenites sp. & & + & \multirow{4}{*}{ Glossopterids } \\
\hline Chordasporites sp. & & + & \\
\hline Falcisporites nuthallensis (Clarke) Balme, 1970 & & + & \\
\hline Falcisporites zapfei Leschik, 1956 & & + & \\
\hline Striatopodocarpites diffusus Bharadwaj \& Salujha, 1964 & & + & \multirow{6}{*}{ Conifers } \\
\hline Faunipollenites parvus Tiwari, 1965 & & + & \\
\hline Faunipollenites goraensis (Potonié \& Lele) Maithy, 1965 & & + & \\
\hline Crescentipollenites globosus (Maithy) Jha, 1996 & & + & \\
\hline Crescentipollenites brevis (Bose \& Kar) Bhardwaj, Tiwari \& Kar, 1974 & & + & \\
\hline Crescentipollenites gondwanensis (Maheshwari) Bharadwaj, Tiwari \& Kar, 1974 & & + & \\
\hline
\end{tabular}


Table 2. Continuation.

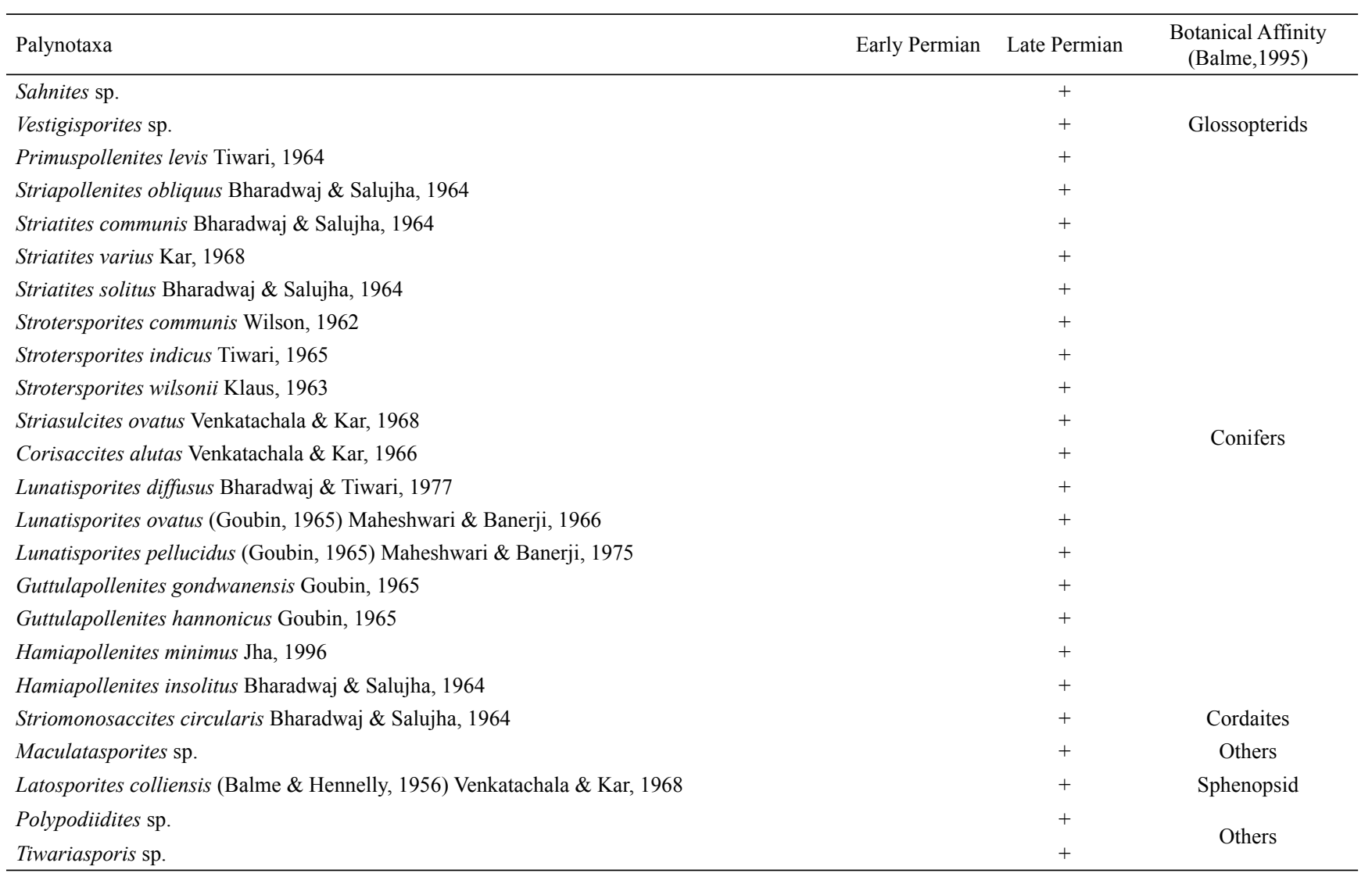

\section{Palynoassemblage III}

Recorded palynoflora. The youngest Palynoassemblage III has been demarcated between 46.75-206.70 m (samples 2-19, Figures 2,7 ) by the dominance of Striasulcites (4-30\%) and subdominance of Faunipollenites (4.9-20\%), Striatopodocarpites (3-34\%) and Scheuringipollenites (4-45\%). Other associated genera of this palynoassemblage are triletes: Callumispora (0.5-1.5\%), Leiotriletes (1-11\%), Brevitriletes (0.5$1.5 \%)$, Lacinitriletes (1-4\%), Verrucosisporites (1\%), Indotriradites (0.5-10.5\%), Microbaculispora (0.5-8\%), Microfoveolatispora (0.5-5\%), Horriditriletes ( $0.5 \%)$; monosaccates: Densipollenites (0.5-3.5\%), Plicatipollenites (0.5-3.5\%), Caheniasaccites (0.5-5\%), Parasaccites (0.56\%), Potonieisporites (0.5-5\%), Divarisaccus (0.5-2.5\%); non-striate disaccates: Ibisporites (1-11.2\%), Sahnites (0.5$1 \%)$, Platysaccus (0.5-2.8\%), Primuspollenites (1-2.5\%); striate disaccates: Crescentipollenites (1-20\%), Striatites (0.7-7.5\%), Polypodiidites (1\%); aletes: Inaperturopollenites (0.5-1.4\%), Latosporites (0.5-2\%), Maculatasporites (0.5-2.5\%), Tiwariasporis (1\%). Beside, these some marked stratigraphically significant taxa are Falcisporites (0.5-7.5\%), Klausipollenites (0.5-2.5\%), Chordasporites (1-5\%), Striomonosaccites (0.5-2\%), Lunatisporites (1.5$11.9 \%)$, Strotersporites (1-15.5\%), Corisaccites (0.5-1.4\%), Hamiapollenites (0.5-2\%), Guttulapollenites (1-3\%), Weylandites $(0.5-10 \%)$. Striapollenites has also been recorded in this palynoassemblage.
Botanical affinity. Palaeovegetaion of Palynoassemblage III has also been represented by the dominance of conifers $(>50 \%)$ Faunipollenites bharadwajii, F. (=Protohaploxypinus) varius, F. parvus, F. goraensis, Striatopodocarpites diffuses, S. tiwarii, Lunatisporites diffusus, L. ovatus, L. pellucidus, Primuspollenites levis. Sub-dominant glossopterids of this palaeovegetation are mainly represented by Scheuringipollenites maximus, S. tentulus, Ibisporites jhingurdahiensis, Falcisporites nuthallensis, F. zapfei, Weylandites circularis while, the cordaites (25\%) are distinguished by the presence of Parasaccites distinctus, P. korbaensis, P. obscures, Densipollenites indicus, D. magnicorpus, Plicatipollenites ganjraensis, Caheniasaccites sp., Primuspollenites levis, Potonieisporites sp., and Divarisaccus sp. Spores are represented by the small association of filicopsids (Polypodiidites sp., Horriditriletes rampurensis, Brevitriletes communis, B. unicus, Verrucosisporites gondwanensis, Microfoveolatispora sp., Microbaculispora sp. Leiotriletes sp.), lycopsids (Callumispora sp., Indotriradites sp.) and sphenopsids (Latosporites colliensis).

Age. Guadalupian age (Aggarwal \& Jha, 2013).

Comparison. Palynoassemblage III correlates with Palynozone-F of Johilla Coalfield of Son Valley (Tiwari \& Ram Awatar, 1989) in having the presence of Striatopodocarpites, Crescentipollenites, Faunipollenites, Callumispora, Klausipollenites; Assemblage-II of Mantheni Area of Godavari Graben (Bharadwaj et al., 1987); Palynoassemblage II from Ramagundam, Khammampalli and Manuguru areas (Srivastava \& Jha, 1988); Assemblage-IV of 

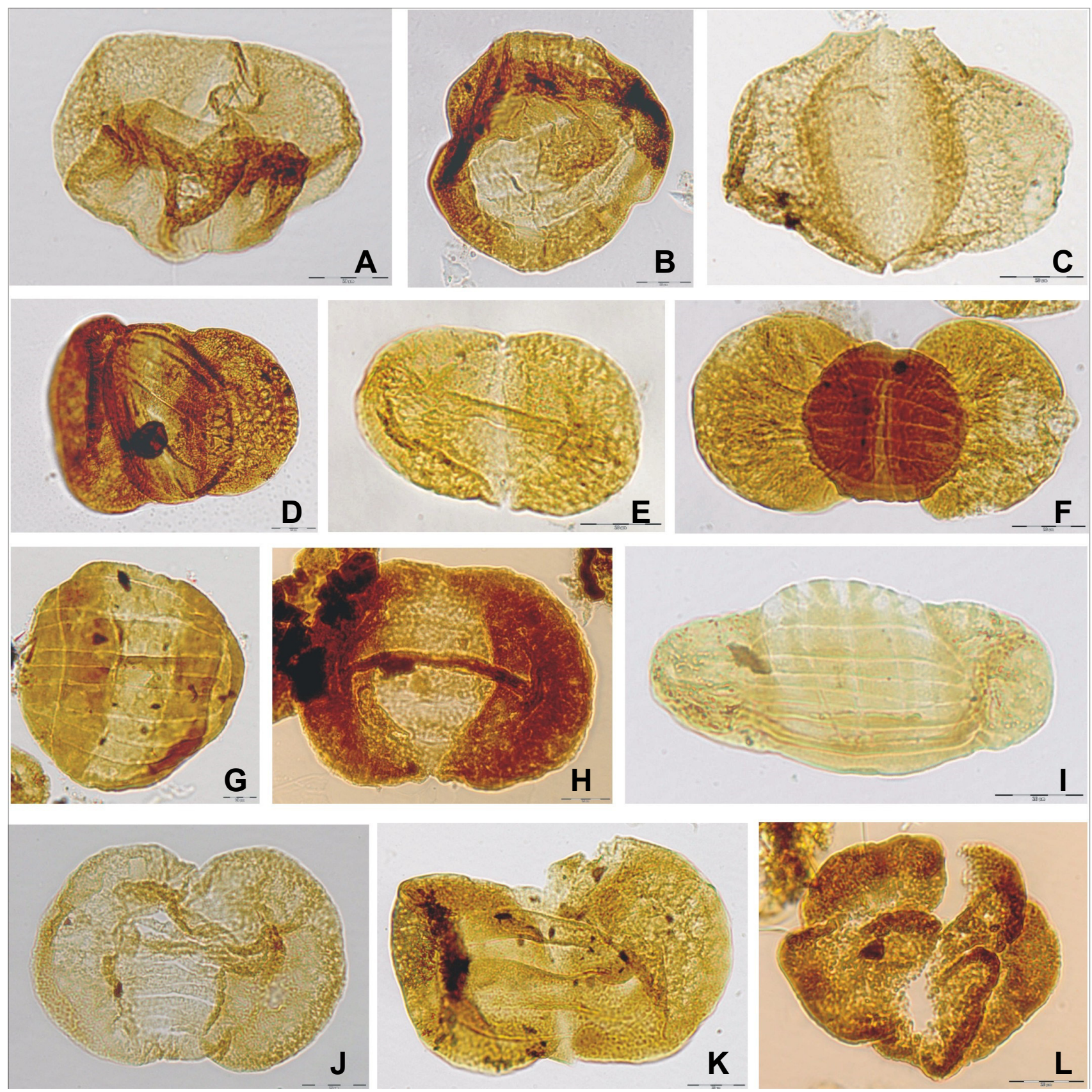

Figure 3. Plate showing Permian palynotaxa in borecore MGK-6 Kachinapalli area, Godavari Graben. A, Densipollenites magnicorpus, B.S.I.P. Slide No. 14019a, N42-2. B, Striomonosaccites circularis, B.S.I.P. Slide No. 14020, M53-4. C, Falcisporites zapfei, B.S.I.P. Slide No. 13980, O57-2. D, Striapollenites obliquus, B.S.I.P. Slide No. 14021, K41-2. E, Strotersporites sp., B.S.I.P. Slide No. 14022, D55. F, Striatites varius, B.S.I.P. Slide No. 14022, F33-4. G, Striasulcites ovatus, B.S.I.P. Slide No. 14023a, R55-2. H, Strotersporites indicus, B.S.I.P. Slide No. 13574, S49-2. I, Hamiapollenites insolitus, B.S.I.P. Slide No. 14024, E52-2. J, Lunatisporites sp., B.S.I.P. Slide No. 14020a, F55-3. K, Lunatisporites pellucidus, B.S.I.P. Slide No. 14025, J60-3. L, Guttulapollenites hannonicus, B.S.I.P. Slide No. 13577, M51-1. Scales bars = 20 um.

Talcher Coalfield, Orissa (Tiwari et al., 1991); Palynozone-2 of Bazargaon, Nagpur (Srivastava \& Bhattacharya, 1996); Palynozone-5 of Mailaram area (Jha \& Aggarwal, 2012).

In the present study the palynoassemblages have been identified on the basis of the dominance and subdominance of the datum while, if we observe the data of other Gondwana continents then the authors have made the palynozones/ palynoassemblages on the basis of concurrent range zone (South Africa; MacRae, 1988), by the first occurrence of index taxa (Australia; Kemp et al., 1977), etc. In such cases only tentative correlation is possible in place of exact correlation. Late Permian palynoassemblages have also been found tentatively akin to Assemblage Zone-IV of Dwyka of Mid Zambesi basin (Falcon, 1975); Amery Group of East Antarctica, Buckley Formation from Mount Archernar and Fossilryggen Vestfjella Dronning Maund Land, Antarctica (Truswell, 1980; Playford, 1990); Lower Sakamena Group of Madagascar, Karoo Zone 4 and 5 of South Africa and 


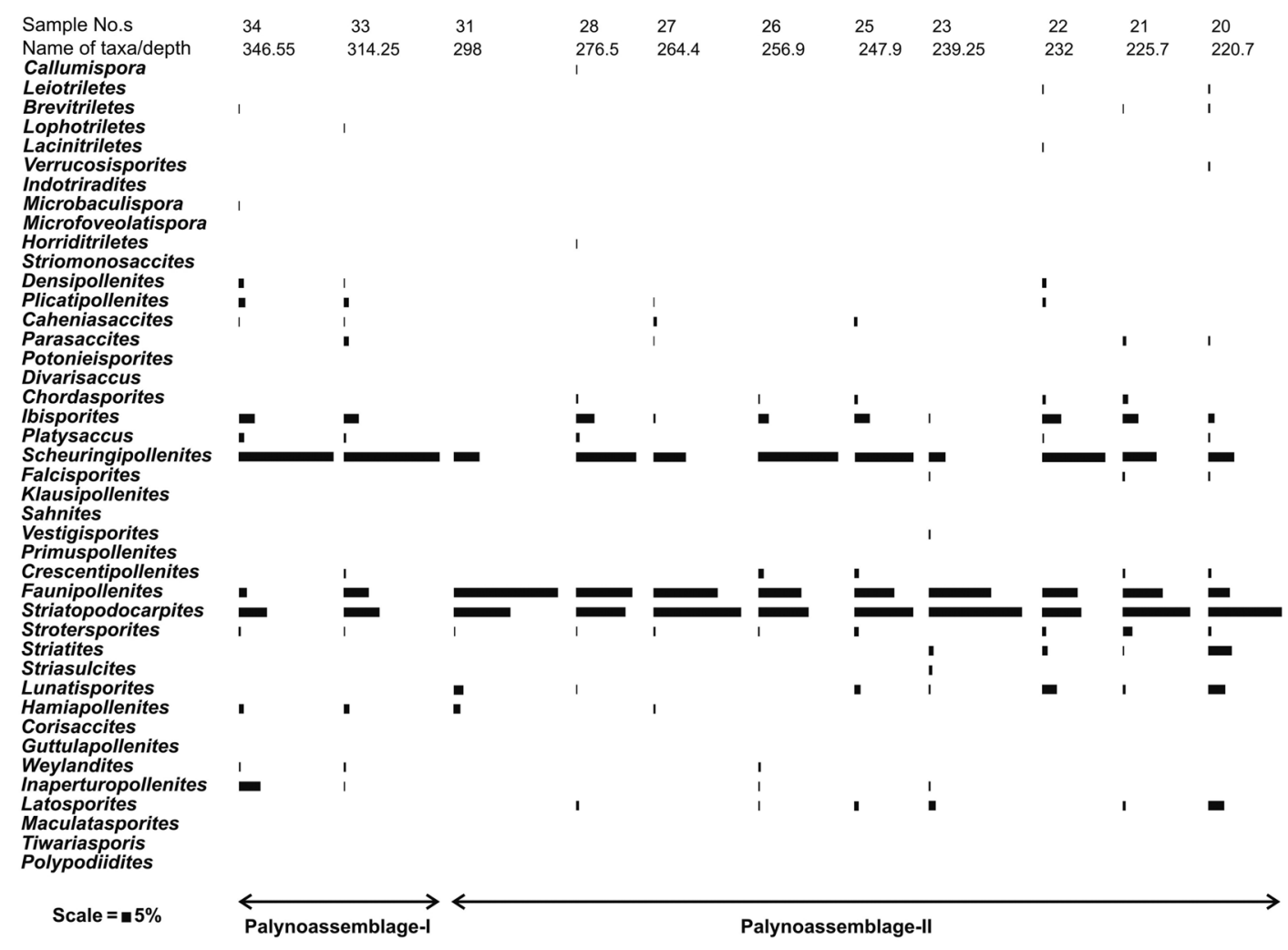

Figure 4. Histogram showing vertical distribution of different palynotaxa in Palynoassemblages I and II of borecore MGK-6, Kachinapalli area, Godavari Graben.
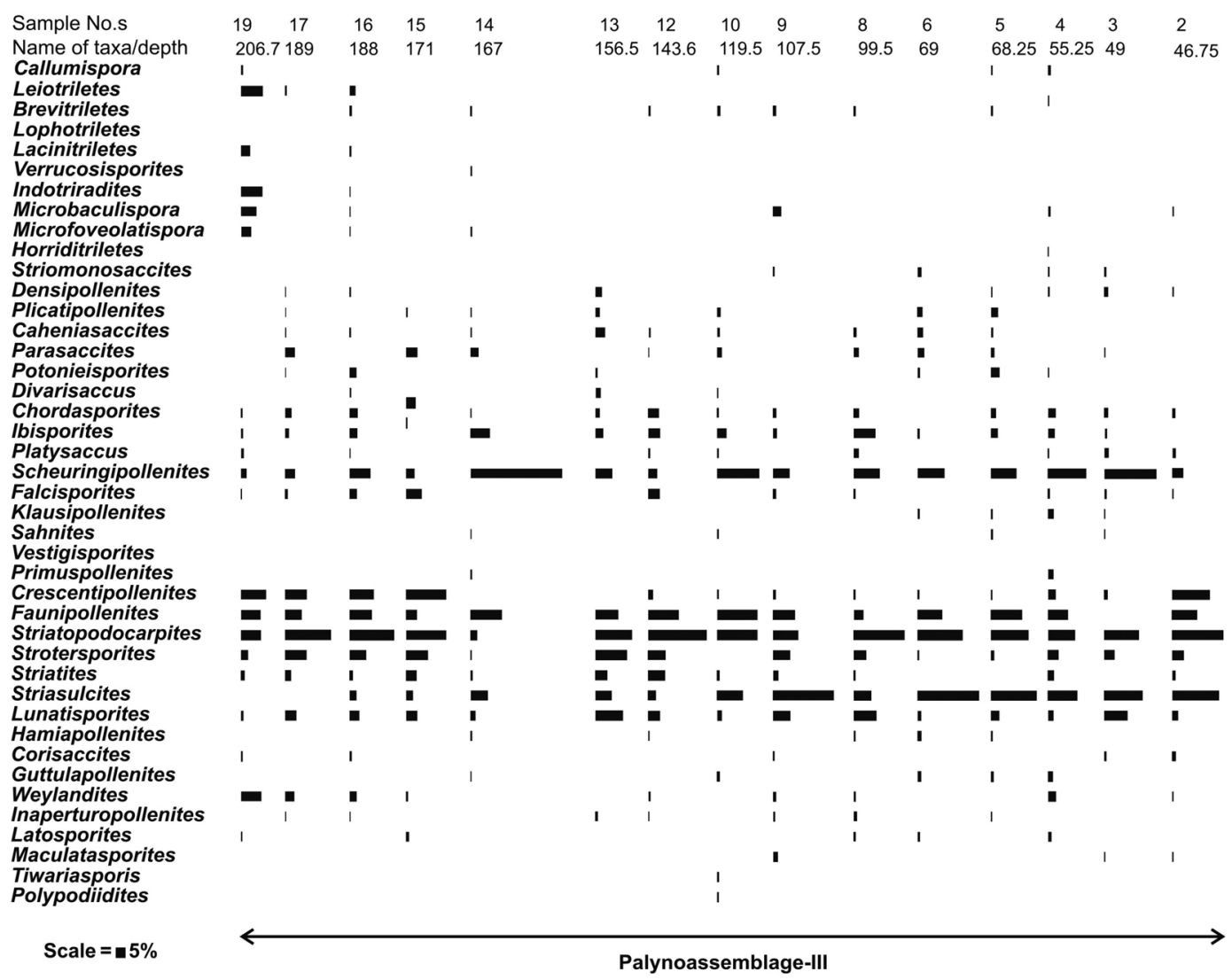

Figure 5. Histogram showing vertical distribution of different palynotaxa in Palynoassemblage III of borecore MGK-6, Kachinapalli area, Godavari Graben. 


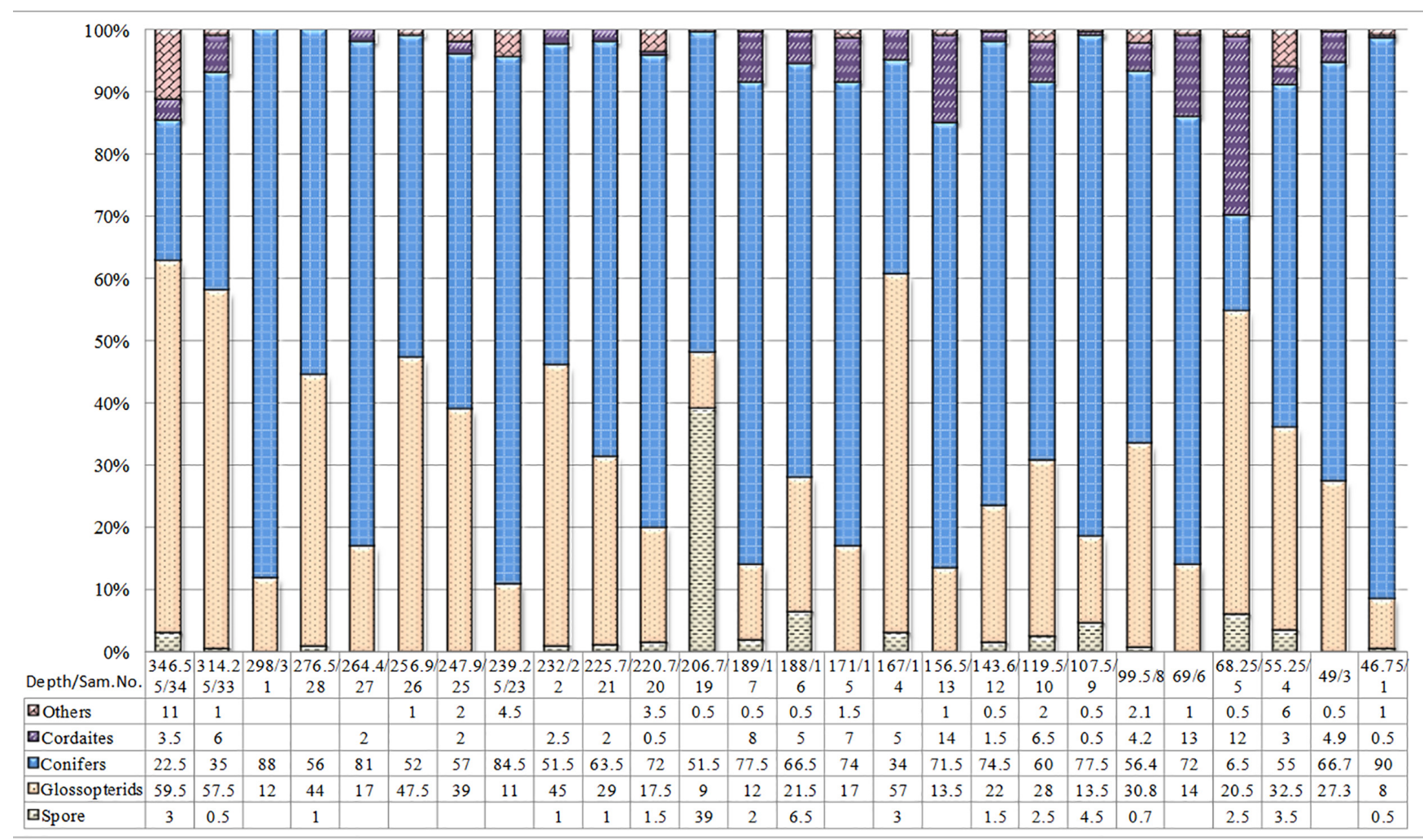

Figure 6. Frequency distribution of different plant types in borecore MGK-6, Kachinapalli area, Godavari Graben.

palynomorph zone of Maduma Basin Mudstone Formation from Mid-Zambia Basin (Nyambe \& Utting, 1997), Upper part of Lueckisporites-Weylandites (LW) and Striatites Assemblage Biozone of Argentina (Césari \& Gutiérrez, 2001; Beri et al., 2011).

\section{DISCUSSION}

\section{Age demarcation on the basis of palynofloral diversity}

In Lower Gondwana palynofloral succession striate disaccates show fairly good representation in Lower Barakar, attain dominance in Upper Barakar and remain dominant component of palynoflora up to the Raniganj Formation (Late Permian). Thus, the striate disaccates loose the stratigraphic significance and the associated taxa become important while identifying the assemblages in Late Permian. The quantitative estimation of various taxa at generic level shows marked changes in mioflora from Early Permian to Late Permian. In Godavari Graben, total 12 palynoassemblages have been defined in Lower Gondwana succession on the basis of dominance and sub-dominance of striate and non-striate disaccates. Palynocomposition of Permian (Lower Gondwana) palynoassemblages in Godavari Graben has been described by Jha (2006) in detail. On the basis of palynological studies we have found only three out of twelve palynoassemblages in the presently studied borecore.

The dominance of non-striate disaccates viz., Scheuringipollenites, Ibisporites and sub-dominance of striate disaccates viz., Striatopodocarpites, Faunipollenites,
Crescentipollenites in Palynoassemblage I (314.25-346.65 m) suggests the Barakar palynoflora (Early Permian), dominance of striate disaccates viz., Faunipollenites, Striatopodocarpites, Striasulcites and sub-dominance of nonstriate disaccate Scheuringipollenites alongwith some stratigraphically significant taxa viz., Lunatisporites, Falcisporites, Klausipollenites, Striomonosaccites, Chordasporites, Weyladites, Corisaccites, Guttulapollenites, Strotersporites, Hamiapollenites in Palynoassemblage-II (220.70-298 m) and Palynoassemblage III $(46.75-206.70 \mathrm{~m})$ suggests the Raniganj palynoflora (Late Permian). Hence, it is inferred that Palynoassemblage I was preserved during Artinskian age and the rest two; Palynoassemblage II and Palynoassemblage III were preserved during Guadalupian age.

\section{Floristic changes and paleoecological variability}

The present Kachinapalli palynoflora confirmed the dominance of gymnosperm pollen grains mainly assignable to glossopterids (Scheuringipollenites maximus, S. tentulus, Ibisporites jhingurdahiensis) and conifers (Faunipollenites bharadwajii, F. (=Protohaploxypinus) varius, F. parvus, F. goraensis, Striatopodocarpites tiwarii, S. diffuses, Lunatisporites diffusus, L. ovatus, L. pellucidus, Primuspollenites levis). Glossopterids grow in mesophylous to xerophylous palaeoenvironment, flourished in lowland peats while conifers were carried out from more distant areas to the mires (Knoll \& Nicklas, 1987).

Conifers are considered to be extrabasinal or hinterland elements which typically show several adaptations for 


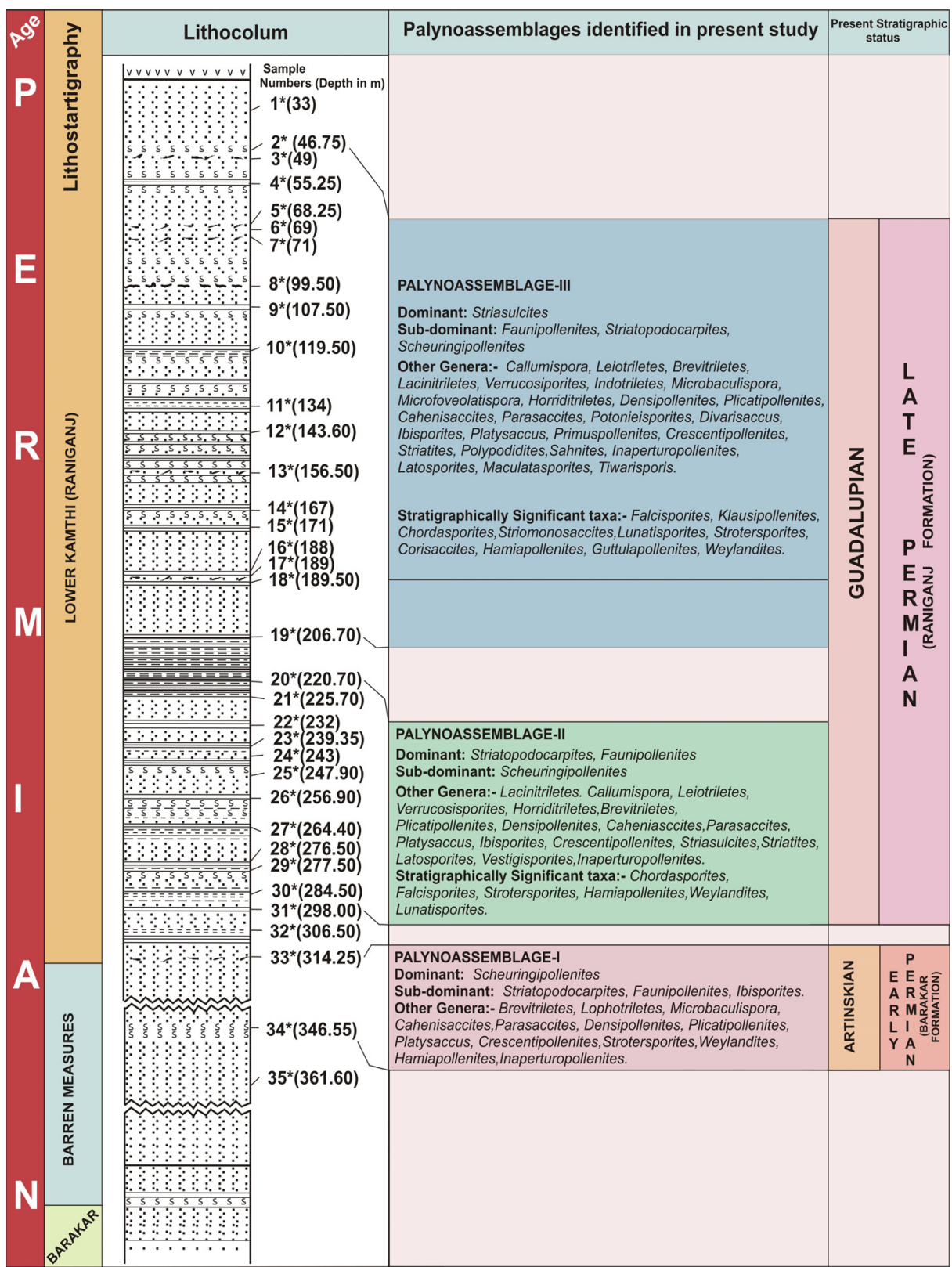

Figure 7. Diagrammatic representation of identified palynoassemblages at the different depths of borecore-MGK-6.

survival in drier habitats. Likely less frequent cordaites (Caheniasaccites distinctus, C. ovatus, C. ellipticus, Plicatipollenites indicus, P. ganjraensis, Densipollenites invisus, D. indicus, D. magnicorpus, Parasaccites distinctus, $P$. korbaensis, P. obscures, Caheniasaccites sp., Primuspollenites levis, Potonieisporites sp., Divarisaccus sp.), also grow from the more distant areas from the palaeomire, where they are scarcely preserved (Cazzulo-Klepzig et al., 2005). Cordaitophytic pollen grains also love the mesophilous palaeoenvironemnt near the mire and palaeoecologically they inhabited in well drained, clastic low land substrates (Taylor \& Taylor, 1993). Fragmentary presence of cordaites recommends the incursion of remnants of a parautochthonous seasonal dryland flora in the depositional environment (Jasper et al., 2006).
Low percentage of pteridophytic spores belonging to Filicopsids (Lophotriletes rectus, Microbaculispora sp., Horriditriletes rampurensis, Brevitriletes communis, B. unicus, Verrucosisporites gondwanensis Polypodiidites sp., Verrucosisporites gondwanensis, Microfoveolatispora sp., Microbaculispora sp., Leiotriletes sp.), lycopsids (Callumispora sp., Indotriradites sp.) and sphenopsids (Latosporites colliensis) flourish in hygrophilous to mesophylous paleoenvironment. Some authors viz., Rothwell (1988), DiMichele \& Phillips $(1985,1994)$ suggested that these spores might have a capacity to tolerate the flooded environment because of their reproductive strategies and specialized growth.

On the basis of botanical affinity the dominance of glossopterids (Scheuringipollenites maximus, S. tentulus, 
Ibisporites jhingurdahiensis) and conifers (Striatopodocarpites decorus, Faunipollenites (= Protohaploxypinus) varius, F. bharadwajii, F. goraensis, Striasulcites ovatus, Crescentipollenites globosus) in the palynofloras represents a peat-forming community. Contributory cordaites, triletes pteridophytic spores belonging to lycopsids, sphenopsids and filicopsides are less and variable in percentage. Algae like elements (Maculatasporites) are very few or rarely present. Such type of palynofloral composition is very common in Indian coal palynoflora. Dominance of woody seed plants, variable-low percentage of pteridophytic plants along with scant percentage of algal form suggests the peat swamp forming vegetation (Guerra-Sommer et al., 1983) in telmatic environment (forest moor) in a habitat with periods of standing water (Teichmuller, 1962). Similar type of palaeoenvironment has also been interpreted in Brazil (Guerra-Sommer et al., 1983; Cazzulo-Klepzig et al., 2007). The dominance of arborescent vegetation, low proportion of spores (lycopsids, sphenopsids and filiciopsids) and diminutive presence of algal elements suggests that Kachinapalli palaeomire landscape was located in more inland area and the coal was formed in wet forest environment situated in fresh water setting. In the whole succession at some places a very good percentage of spores represent the flooding environment signatures in the palaeomire.

\section{CONCLUSIONS}

Lithologically Barren Measures and Kamthi formations have been demarcated between 306.50-475.30 m and 6-306.20 m, respectively, while on the basis of palynological studies in borecore MGK-6 falls under two groups: Palynoassemblage I, belonging to Artinskian age, and the rest two (Palynoassemblage II \& III) belonging to Guadalupian age. The palynoflora present at the depth of 314.25-346.55 $\mathrm{m}$ shows continuation of Artinskian palynoflora, while the sediments between 220.70-298 $\mathrm{m}$ and 46.75-206.70 $\mathrm{m}$ have its equivalence with the Guadalupian palynoflora.

The presence of Barren Measures Formation in this sequence appear debatable (Figure 7). It is reasonable to assume that Barakar sedimentation has continued up to $306.50 \mathrm{~m}$ and the sedimentation through Barren Measures time is not preserved. However, no break in sedimentation is documented.

The complete succession of the present study represents a clear picture of the fluvial river channel deposit along with some sub-environments like flood plain, lake, lagoon, swamp and wetlands. On the basis of palynofloral components the present succession represents a peat-forming community mainly composed of glossopterids, cordaites and conifers. Contributory trilete pteridophytic spores belonging to lycopsids, sphenopsids and filicopsids are less and variable in percentage. Algae like elements (Maculatasporites) are very few or rarely present. Dominance of woody seed plants, variable-low percentage of pteridophytic plants along with scarce percentage of algal forms, suggests the peat swamp forming vegetation in telmatic environment (forest moor) in a habitat with periods of standing water.

\section{ACKNOWLEDGEMENTS}

The authors express their thanks to the director, B.S.I.P., for the permission to publish the results. Thanks are extended to Singareni Collieries Company Limited (SCCL) and Mineral Exploration Corporation Limited (MECL) for the permission to collect the samples. Special thanks to S.M.B. Chari, former CGM, SCCL for providing the field assistance. Authors express their sincere thanks to I. Mendes, for the Portuguese translation. Authors also express their sincere gratitude to anonymous reviewers, for many valuable suggestions to improve the quality of this manuscript.

\section{REFERENCES}

Aggarwal, N. \& Jha, N. 2013. Permian palynostratigraphy and palaeoclimate of Lingala-Koyagudem Coalbelt, Godavari Graben, Andhra Pradesh, India. Journal of Asian Earth Sciences, 64:38-57. doi:10.1016/j.jseaes.2012.11.041

Balme, B.E. 1995. Fossil in situ spores and pollen grains: an annotated catalogue. Review of Palaeobotany and Palynology, 87:81-323. doi:10.1016/0034-6667(95)93235-X

Beri, A.; Gutiérrez, P. \& Balarino, L. 2011. Palynostratigraphy of the Late Palaeozoic of Uruguay, Paraná Basin. Review of Palaeobotany and Palynology, 167:16-29. doi:10.1016/j. revpalbo.2011.05.004

Bharadwaj, D.C.; Srivastava, S.C.; Ramanamurty, B.V. \& Jha, N. 1987. Palynology of Kamthi Formation from Ramagundam-Mantheni Area, Godavari Graben, India. The Palaeobotanist, 35:318-330.

Bhattacharyya, A.P. 1997. Palynological recognition of the Karharbari-Barakar Formations in the sub-surface sediments of Wardha Coalfield, Maharashtra, India. The Palaeobotanist, 46:217-219.

Cazzulo-Klepzig, M.; Guerra-Sommer, M.; Menegat, R.; Simas, M.W. \& Mendonça Filho, J.G. 2007. Peat-forming environment of Permian coal seams from the Faxinal coalfield (Paraná Basin) in Southern Brazil based on palynology and palaeobotany. Revista Brasileira de Paleontologia, 10:117-127.

Cazzulo-Klepzig, M.; Menegat, R. \& Guerra-Sommer, M. 2005. Palynology and palaeobotany in the reconstruction of landscape units from the Candiota coalfield, Permian of Paraná Basin, Brazil. Revista Brasileira de Paleontologia, 8:83-98.

Césari, S.N. \& Gutiérrez, P.R. 2001. Palynostratigraphy of Upper Paleozoic sequences in Central-Western Argentina. Palynology, 24:113-146. doi:10.1080/01916122.2000.9989541

Di Michele, W.A. \& Phillips, T.L. 1985. Arborescent Lycopod reproduction and paleoecology in a coal-swamp environment of late middle Pennsylvanian age (Herrin Coal, Illinois, USA). Review of Palaeobotany and Palynology, 44:1-26. doi:10.1016/0034-6667(85)90026-0

Di Michele, W.A. \& Philips, T.L. 1994. Palaeobotanical and palaeoecological constrains on models of peat-formation in the Late Carboniferous in Euramerica. Palaeogeography, Palaeoclimatology, Palaeoecology, 106:39-90. doi:10.1016/0031-0182(94)90004-3

Falcon, R.M.S. 1975. Palynostratigraphy of the Karroo sequence in the central Sebungwe District, Mid zambesi Basin, Rhodesia. Palaeontographica Africana, 18:1-29.

Gore, J.W. 2010. Depositional Sedimentary Environments. Department of Geology, Georgia Perimeter College Clarkston, p. 131-144. 
Gould, R.E. \& Delevoryas, T. 1977. The biology of Glossopteris: evidence from petrified seed-bearing and pollen-bearing organs. Alcheringa, 1:87-399. doi:10.1080/03115517708527774

Guerra-Sommer, M.; Marques-Toigo, M.; Paim, P.S.G.; Henz, G.I.; Skilveira, J.B.R. \& Backeuser, Y. 1983. Estudo micoflorístico e petrológico dos carvões da Mina do Faxinal, Formação Rio Bonito (Permiano), RS. Boletim IG-USP, Série Científica, 15:73-83.

Jasper, A.; Menegat, R.; Guerra-Sommer, M.; Cazzulo-Klepzig, M. \& Souza, P.A. 2006. Depositional cyclicity and paleoecological variability in an outcrop of Rio Bonito Formation, Early Permian, Paraná Basin, Rio Grande do Sul, Brazil. Journal of South American Earth Sciences, 21:276-293. doi:10.1016/j. jsames.2006.05.002

Jha, N. 2004. Palynological dating of coal-bearing sediments from the Bottapagudem area, Chintalapudi sub-basin, Andhra Pradesh. The Palaeobotanist, 53:61-67.

Jha, N. 2006. Permian palynology from India and Africa: a phytogeographical paradigm. Journal of the Palaeontological Society of India, 51:43-55.

Jha, N. \& Aggarwal, N. 2012. Permian-Triassic palynostratigraphy in Mailaram area, Godavari Graben, Andhra Pradesh, India. Journal of Earth System Science, 121:1257-1285. doi:10.1007/ s12040-012-0224-4

Kemp, E.M.; Blame, B.E.; Helby, R.A.; Playford, G. \& Price, P.L. 1977. Carboniferous and Permian palynostratigraphy in Australia and Antarctica: a review. BMR Journal of Australian Geology and Geophysics, 2:177-208.

Knoll, J. \& Nicklas, E. 1987. Adaptation, plant evolution, and the fossil record. Review of Palaeobotany and Palynology, 72:886887. doi:10.1016/0034-6667(87)90043-1

MacRae, C.S. 1988. Palynostratigraphic correlation between the Lower Karoo sequence of the Waterberg and Pafuri coal bearing basins and the Hammanskraal plant microfossil locality. Republic of South Africa. Arcadia, Department Mineral Energy, Geological Survey, 217 p. (Memoir 75).

Manum, S.B. \& Tien, N.D. 1973. Palynostratigraphy of the Ketewaka Coalfield (Lower Permian). Review of Palaeobotany and Palynology, 16:213-227. doi:10.1016/0034-6667(73)90020-1

MECL, 2002. Geological report on regional exploration for coal in Mamakannu block, Godavari Valley Coalfield, LingalaKoyagudem Coalbelt. Khammam District, Andhra Pradesh, India.

Nyambe, I. \& Utting, J. 1997. Stratigraphy and palynostratigraphy Karoo super group (Permian and Triassic) Mid Zambesi Valley southern Zambia. Journal of African Earth Sciences, 24:563-583. doi:10.1016/s0899-5362(97)00081-x

Playford, G. 1990. Proterozoic and Palaeozoic palynology of Antarctica: a review. In: T.N. Taylor \& E.L Taylor (eds.) Antarctic Palaeobiology: its role in reconstruction of Gondwana. Springer-Verlag, p. 51-70. doi:10.1007/978-1-4612-3238-4 6

Raja Rao, C.S. 1982. Coalfield of India-2. Coal resources of Tamil Nadu, Andhra Pradesh, Orissa and Maharashtra. Rasoolpura, Geological Survey of India, p. 9-40 (Series A 45).

Ram-Awatar. 1996. Palynozonation of Middle Pali Member in Sohagpur Coalfield, Madhya Pradesh. The Palaeobotanist, 43:96-101.
Ram-Awatar; Mukhopadhyay, A. \& Adhikari, S. 2003. Palynostratigraphy of subsurface Lower Gondwana, Pali sediments, Sohagpur Coalfield, Madhya Pradesh, India. The Palaeobotanist, 53:51-59.

Rothwell, G.W. 1988. Cordaitales. In: C.B. Beck (ed.) Origin and evolution of Gymnosperms, Columbia University Press, p. 273-297.

Semkiwa, P.; Kalkeuth, W.; Utting, J.; Mayagilo, F.; Mpanju, F. \& Hagemann, H. 1998. The geology, petrology, palynology and geochemistry of Permian coal basin in Tanzania, Namwele Mkomolo, Muze Galula Coalfields. International Journal of Coal Geology, 36:63-110. doi:10.1016/S0166-5162(97)00020-7

Smith, A.H.V. 1962. The palaeoecology of Carboniferous peats based on the miospores and petrography of bituminous coals. Proceedings of Yorkshire Geological Society, 33:345-363.

Srivastava, S.C. \& Bhattacharyya, A.P. 1996. Permian-Triassic palynofloral succession in subsurface from Bazargaon. Nagpur District, Maharashtra. The Palaeobotanist, 43:10-15.

Srivastava, S.C. \& Jha, N. 1986. Palynology of Kamthi Formation from Chelpur area, Godavari Graben, Andhra Pradesh, India. The Palaeobotanist, 35:342-346.

Srivastava, S.C. \& Jha, N. 1988. Palynology of Kamthi Formation in Godavari Graben. The Palaeobotanist, 36:123-132.

Srivastava, S.C. \& Jha, N. 1992a. Permian palynostratigraphy in Ramakrishnapuram area, Godavari Graben, Andhra Pradesh, India. Geophytology, 20:83-95.

Srivastava, S.C. \& Jha, N. 1992b. Palynostratigraphy of Permian sediments in Manuguru area Godavari Graben, Andhra Pradesh. Geophytology, 22:103-110.

Srivastava, S.C. \& Jha, N. 1994. Palynological dating of Lower Gondwana sediments in Sattupalli area, Cintalapudi subbasin, Andhra Pradesh, India. The Palaeobotanist, 42:169-173.

Taylor, T.N. \& Taylor, E.L. 1993. The biology and evolution offossil plants. New Jersey, Prentice-Hall Inc., 982 p.

Teichmuller, M. 1962. Die Genese der Kohle. C.R. In: CONGRESS ON INTERNATIONAL STRATIGRAPHY GEOLOGICA, CARBONIFERE, 4, 1959. Abstracts, Heerlen, p. 699-722.

Tripathi, A. 1997. Palynostratigraphy and palynofacies analysis of subsurface Permian sediments in Talcher Coalfield, Orissa. The Palaeobotanist, 46:79-88.

Tiwari, R.S. \& Ram-Awatar 1989. Sporae dispersae and correlation of Gondawna sediments in Johilla Coalfield, Son Valley Graben, Madhya Pradesh. The Palaeobotanist, 37:94-114.

Tiwari, R.S. \& Tripathi, A. 1992. Marker Assemblage zones of spore and pollen species through Gondwana Palaeozoic-Mesozoic sequence in India. The Palaeobotanist, 40:194-236.

Tiwari, R.S.; Tripathi, A. \& Jana, B.N. 1991. Palynological evidence for Upper Permian Raniganj Coals in western part of Talcher Coalfield, Orissa, India. Current Science, 61:407-420.

Truswell, E.M. 1980. Permo-Carboniferous palynology of Gondwanaland: progress and problem in the decade to 1980 . BMR Journal of Australian Geology and Geophysics, 5:95-111.

Received in February, 2014; accepted in April, 2015. 